\title{
ANALISIS KUALITAS AUDITOR, LEVERAGE DAN PERSENTASE SAHAM INITIAL PUBLIC OFFERING TERHADAP EARNINGS MANAGEMENT PERUSAHAAN GO PUBLIC
}

\author{
HASANUDDIN, MURYANI ARSAL \\ Universitas Muhammadiyah Makassar, Makasar, Indonesia \\ *Email: hasanuddin_feb@unismuh.ac.id
}

\begin{abstract}
The action of corporate management to intervene in the process of drafting financial statements is an act of dysfunctional behavior that will affect the enhancement of personal welfare management and The company's employees and the value of its leadership. This research aims to test and prove empirically the cause and influence of earnings management in the company that go public after the enactment of Accounting and Auditing Enforcement Release (AAER) by Security Exchange Commission (SEC). The variables tested were reputation Auditor, Leverage and stock percentage of Initial Public Offering (IPO) at the company that go Public on the Indonesia Stock Exchange from 2000 to 2004. The method of analysis used is multiple regression that previously done testing through several stages. Results show that the leverage variable significantly affects earnings management. This indicates that the debt that is the source of external funds used to finance the business continuity is strongly associated with earnings management.
\end{abstract}

Keywords: earnings management, leverage, initial offering public.

\section{PENDAHULUAN}

Belkoui (1993) dalam tulisannya mengatakan bahwa laporan keuangan merupakan sarana untuk mempertanggungjawabkan apa yang dilakukan oleh manajer atas sumber daya pemilik. Selain itu, laporan keuangan merupakan alat untuk mengukur kinerja perusahaan serta media komunikasi yang digunakan untuk menghubungkan pihak-pihak yang berkepentingan terhadap perusahaan dan salah satu parameter penting dalam laporan keuangan yang digunakan untuk mengukur kinerja manajemen adalah laba.

Menurut Statement of Financial Accounting Concepts (SFAC) No. 1, informasi laba merupakan faktor yang menjadi perhatian utama dalam menaksir kinerja atau pertanggungjawaban manajemen. Selain itu informasi laba juga 
Jurnal Ilmiah Akuntansi Universitas Pamulang - Vol. 7, No. 2, Juli 2019 - Hasanuddin \& Arsal

membantu pemilik atau pihak lain dalam menaksir earnings power perusahaan di masa yang akan datang. Kecenderungan untuk lebih memperhatikan laba ini disadari oleh manajemen, khususnya manajer yang kinerjanya diukur berdasarkan informasi tersebut, sehingga mendorong terjadinya dysfunctional behaviour (perilaku menyimpang), yang salah satu bentuknya adalah earnings management.

Dechow, et.al (1996) mendefinisikan earnings management sebagai earnings manipulation, baik didalam maupun diluar batas Generally Accepted Accounting Principles (GAAP). Sementara Scott (1997) mendefinisikan earnings management sebagai tindakan manajemen untuk memilih kebijakan akuntansi dari suatu standar tertentu dengan tujuan memaksimalkan kesejahteraan dan atau nilai pasar perusahaan. Ungkapan tersebut di atas menjadi acuan bagi peneliti untuk membatasi earnings didasarkan pada sifatnya, sebab masih adanya kerancuan mengenai terminologi earnings dalam Standar Akuntansi Keuangan (SAK) Indonesia. Dalam penelitian ini, peneliti mengasumsikan earnings terdiri atas laba tunai dan komponen-komponen akrual baik yang berada di bawah kebijakan manajemen (discretionary) maupun yang tidak (nondiscretionary).

Watt dan Zimmerman dalam Sugiri (1998) membagi motivasi earnings management menjadi 3, yakni bonus plan hypothesis, debt to equity hypothesis, dan political cost hypothesis. Hipotesis bonus plan menyatakan bahwa manajer pada perusahaan dengan bonus plan cenderung untuk menggunakan metode akuntansi yang akan meningkatkan income saat ini. Debt to equity hypothesis menyebutkan bahwa pada perusahaan yang mempunyai rasio debt to equity besar maka manajer perusahaan tersebut cenderung menggunakan metode akuntansi yang akan meningkatkan pendapatan maupun laba. Adapun political cost hypothesis menyatakan bahwa pada perusahaan yang besar, yang kegiatan operasinya menyentuh sebagian besar masyarakat akan cenderung untuk mengurangi laba yang dilaporkan.

Dechow, et.al (1996) mengidentifikasi faktor demand for external financing, insider trading, debt, bonus, dan governance structure sebagai faktor-faktor yang berpengaruh terhadap earnings management. Terdapat berbagai macam proxy yang digunakan untuk mengukur faktor-faktor tersebut. Beberapa diantaranya adalah leverage dan reputasi auditor. Selain kedua faktor tersebut, penelitian ini juga menambahkan satu faktor baru, yaitu persentase saham yang ditawarkan kepada publik saat IPO.

\section{LANDASAN TEORI}

\section{Agency Theory}

Menurut Anthony dan Govindaran (1995:569), konsep Agency Theory adalah konsep yang menyatakan hubungan atau kontrak antara principal dan agent. Principal mempekerjakan agent untuk melakukan tugas untuk kepentingan principal, termasuk pendelegasian otoritas pengambilan keputusan dari principal kepada agent. Pada perusahaan yang modalnya terdiri atas saham, pemegang saham bertindak sebagai principal, dan Chief Executive Officer (CEO) sebagai agent mereka. Agency theory memiliki asumsi bahwa masing-masing individu

* Corresponding author's e-mail: hasanuddin_feb@unismuh.ac.id

http://openjournal.unpam.ac.id/index.php/JIA 
Jurnal Ilmiah Akuntansi Universitas Pamulang - Vol. 7, No. 2, Juli 2019 - Hasanuddin \& Arsal

semata-mata termotivasi oleh kepentingan dirinya sendiri sehingga menimbulkan konflik kepentingan antara principal dan agent. Pihak principal termotivasi mengadakan kontrak untuk menyejahterakan dirinya dengan profitabilitas yang selalu meningkat. Agent termotivasi untuk memaksimalkan pemenuhan kebutuhan ekonomi dan psikologisnya, antara lain dalam hal memperoleh investasi, pinjaman, maupun kontrak kompensasi. Konflik kepentingan semakin meningkat terutama karena principal tidak dapat memonitor aktivitas $C E O$ seharihari untuk memastikan bahwa $C E O$ bekerja sesuai dengan keinginan pemegang saham.

Principal tidak memiliki informasi yang cukup tentang kinerja agent. Agent mempunyai lebih banyak informasi mengenai kapasitas diri, lingkungan kerja, dan perusahaan secara keseluruhan. Hal inilah yang mengakibatkan adanya ketidakseimbangan informasi yang dimiliki oleh principal dan agent. Ketidakseimbangan informasi inilah yang disebut dengan asimetri informasi. Adanya asumsi bahwa individu-individu bertindak untuk memaksimalkan dirinya sendiri, mengakibatkan agent memanfaatkan adanya asimetri informasi yang dimilikinya untuk menyembunyikan beberapa informasi yang tidak diketahui principal. Asimetri informasi dan konflik kepentingan yang terjadi antara principal dan agent mendorong agent untuk menyajikan informasi yang tidak sebenarnya kepada principal, terutama jika informasi tersebut berkaitan dengan pengukuran kinerja agent.

Berdasarkan penelitian yang dilakukan sebelumnya oleh Watts dan Zimmerman (1986) secara empiris membuktikan bahwa hubungan principal dan agent sering ditentukan oleh angka akuntansi. Hal ini memacu agent untuk memikirkan bagaimana angka akuntansi tersebut dapat digunakan sebagai sarana untuk memaksimalkan kepentingannya. Salah satu bentuk tindakan agent tersebut adalah yang disebut sebagai earnings management.

\section{Earnings Management}

Menurut Sugiri (1998), earnings management secara sederhana dapat dipahami sebagai suatu tindakan/perilaku seorang manajer melalui komponen discretionary accruals melakukan permainan dalam menentukan besarnya earnings. Secara luas, earnings management merupakan suatu tindakan manajer dalam meningkatkan laba atau mengurangi laba yang dilaporkan atas suatu unit dimana manjer bertanggung jawab tanpa memberikan dampak peningkatan/penurunan profitabilitas ekonomis jangka Panjang unit tersebut.

Sementara Surifah (1999), berpendapat bahwa earnings management dapat mengurangi kredibilitas laporan keuangan apabila digunakan untuk pengambilan keputusan karena earnings management merupakan suatu bentuk manipulasi atas laporan keuangan yang menjadi sarana komunikasi antara manajer dan pihak eksternal perusahaan.

Berdasarkan uraian atas kedua pendapat tersebut di atas maka earnings management dinyatakan dalam perspektif opurtunistis. Pada umumnya studi tentang earnings management dinyatakan dalam perspektif opurtunistis dibandingkan perspektif efisiensi. Perspektif efisiensi manyatakan bahwa manajer melakukan pilihan atas kebijakan akuntansi untuk memberikan informasi yang

* Corresponding author's e-mail: hasanuddin_feb@unismuh.ac.id

http://openjournal.unpam.ac.id/index.php/JIA 
Jurnal Ilmiah Akuntansi Universitas Pamulang - Vol. 7, No. 2, Juli 2019 - Hasanuddin \& Arsal

lebih baik tentang cash flow yang akan datang dan untuk meminimalkan agency cost yang terjadi karena konflik kepentingan antara stakeholder dan manajer (Jiambalvo, 1996).

\section{Faktor Yang Menjadi Pemicu Terjadinya Earnings Management}

Menurut Scott (1997: 296-306), faktor yang memicu terjadinya earnings management yaitu taxation motivation, pergantian Chief Executive Officer (CEO), dan Initial Public Offering (IPO) selain faktor yang diuji oleh Dechow et.al (1996) yaitu, reputasi auditor, jumlah dewan direksi, dan leverage. Variabel yang akan diuji dalam penelitian ini adalah mengambil dua variabel yang telah diuji sebelumnya oleh Dechow et.al yaitu, reputasi auditor dan leverage serta satu variabel yang sengaja ditambahkan oleh peneliti yaitu persentase saham yang ditawarkan kepada publik saat Initial Public Offering (IPO).

Reputasi auditor sangat menentukan kredibilitas laporan keuangan. Independensi dan kualitas auditor akan berdampak terhadap pendeteksian earnings management dan sudah menjadi sesuatu yang ma'ruf dalam menilai bahwa auditor yang bereputasi baik dapat mendeteksi kemungkinan adanya earnings management secara lebih dini.

Leverage yang digunakan dalam penelitian ini adalah perbandingan antara utang dan aktiva yang menunjukkan berapa bagian aktiva yang digunakan untuk menjamin utang. Ukuran ini berhubungan dengan keberadaan dan ketat tidaknya suatu persetujuan utang. Perusahaan yang mempunyai rasio leverage tinggi akibat besarnya jumlah utang dibandingkan dengan aktiva yang dimiliki perusahaan, diduga melakukan earnings management karena perusahaan akan terancam default ketika tidak dapat memenuhi kewajiban pembayaran utang pada waktunya.

Menurut Jiambalvo (1996), perusahaan akan berusaha menghindarinya dengan membuat kebijaksanaan yang dapat meningkatkan pendapatan maupun laba. Dengan demikian akan memberikan posisi bargaining yang relatif lebih baik dalam negosiasi atau penjadwalan ulang utang perusahaan.

Persentase saham yang ditawarkan kepada publik saat IPO menunjukkan besarnya private information yang harus di-sharing oleh manajer kepada publik. Private information tersebut merupakan informasi internal yang semula hanya diketahui oleh manajer, seperti:standar yang dipakai dalam pengukuran kinerja perusahaan, keberadaan perencanaan bonus, dan sebagainya. Oleh karena itu, adanya public investor mengakibatkan manajer berkewajiban memberikan informasi internal secara berkala sebagai bentuk pertanggungjawabannya.

Menurut Jensen (1993) publik mempunyai peran penting dalam menciptakan well-functioning governance system karena mereka memiliki financial interest dan bertindak independen dalam menilai manajemen. Semakin besar persentase saham yang ditawarkan kepada publik, maka semakin besar pula informasi internal yang harus diungkapkan kepada publik, sehingga kemungkinan dapat mengurangi intensitas terjadinya earnings management.

\section{Hipotesis}

Ha1 : Reputasi Auditor berpengaruh secara signifikan terhadap earnings management.

* Corresponding author's e-mail: hasanuddin_feb@unismuh.ac.id

http://openjournal.unpam.ac.id/index.php/JIA 
Jurnal Ilmiah Akuntansi Universitas Pamulang - Vol. 7, No. 2, Juli 2019 - Marito \& Prasetya

Ha2 : Leverage berpengaruh secara signifikan terhadap earnings management

Ha3 : Persentase saham yang ditawarkan kepada publik saat Initial Public Offering

berpengaruh secara signifikan terhadap earnings management.

\section{METODE PENELITIAN}

Penelitian ini dilakukan pada perusahaan go public terdaftar dalam Bursa Efek Indonesia. Jenis penelitian ini merupakan explanatory research yang fokus atas hubungan antara variabel-variabel penelitian dan menguji hipotesis yang telah dirumuskan (Singarimbun dan Effendi, 1982:6).

\section{Populasi dan Sampel}

Populasi dalam penelitian ini adalah perusahaan yang telah tercatat dalam Bursa Efek Indonesia sejak tahun 2000 sampai dengan 2004. Jenis data yang digunakan adalah data sekunder berupa laporan keuangan yang berasal dari prospektus, kantor akuntan yang mengaudit perusahaan sampel, leverage, dan persentase saham yang ditawarkan kepada publik saat $I P O$.

\section{Definisi Operasional Variabel} berikut:

Variabel bebas (independent variable) dalam penelitian ini diukur sebagai

1. Reputasi auditor

Variabel ini diukur dengan menggunakan variabel dummy, yaitu dengan menggunakan skala 1 untuk auditor prestigious dan skala 0 untuk auditor non prestigious. Untuk menentukan apakah termasuk auditor prestigious dan auditor non prestigious maka peneliti membuat tabulasi perusahaan sampel dan melakukan pemeringkatan auditor berdasarkan frekuensi auditor melakukan audit atas laporan keuangan perusahaan sampel. Setelah dilakukan perangkingan, 3 kantor akuntan yang dikategorikan prestigious adalah: Prasetyo Utomo \& Co, Hans Tuanakotta \& Mustofa, dan Hanadi Sujendro \& Co. Cara ini telah dilakukan oleh Sunariyah (1993) untuk menguji pengaruh variabel reputasi auditor terhadap ketepatan ramalan laba.

2. Leverage

Variabel ini diukur dengan menggunakan rasio total utang terhadap total aktiva.

3. Persentase saham yang ditawarkan kepada publik saat Initial Public Offering. Variabel ini diukur dengan besarnya persentase saham yang ditawarkan kepada masyarakat saat Initial Public Offering.

Variabel terikat (dependent variable) dalam penelitian ini adalah earnings management yang diukur dengan proxy discretionary accruals (DA).

Penggunaan discretionary accruals sebagai proxy earnings management selain mengacu pada penelitian Dechow et.al (1996), juga dikarenakan pengukuran 
Jurnal Ilmiah Akuntansi Universitas Pamulang - Vol. 7, No. 2, Juli 2019 - Marito \& Prasetya

dengan discretionary accruals saat ini telah dipakai secara luas untuk menguji earnings management hypothesis. Menariknya, karena accruals merupakan kumpulan sejumlah dampak bersih atas kebijakan akuntansi yang mencakup portofolio penentu pendapatan (income). Berdasarkan uraian tersebut, kesimpulannya adalah bahwa perspektif manajerial, accruals menunjukkan instrument-instrumen yang mendukung adanya earnings management. Model yang digunakan untuk menghitung DA adalah sebagai berikut:

$$
\mathrm{DA}_{\text {it }}=\mathrm{TA}_{\text {it }}-\mathrm{NDA}_{\text {it }}
$$

Keterangan:

$\mathrm{DA}_{\text {it }}=$ Discretionary Accruals perusahaan i pada tahun $\mathrm{t}$

$\mathrm{TA}_{\text {it }}=$ Total Accruals perusahaan i pada tahun $\mathrm{t}$

$\mathrm{NDA}_{\text {it }}=$ Non Discretionary Accruals perusahaan i pada tahun $\mathrm{t}$

$$
\frac{(\Delta \mathrm{CAt}-\Delta \mathrm{CLt}-\Delta \text { Cash } \mathrm{t}+\Delta \mathrm{STD} \mathrm{t}-\text { Depr } \mathrm{t}) \mathrm{TA} \mathrm{t}-1}{\mathrm{At}-1}
$$

Keterangan:
$\Delta \mathrm{CA}_{\mathrm{t}}$
: Delta Current Assets pada tahun $\mathrm{t}$
$\Delta \mathrm{CL}_{\mathrm{t}}$
: Delta Current Liabilities pada tahun t
$\Delta \mathrm{Cash}_{\mathrm{t}}$
: Delta Cash and Cash Equivalents pada tahun $\mathrm{t}$
$\Delta \mathrm{STD}_{\mathrm{t}}$
: Delta Debt Include in Current Liabilities pada tahun $\mathrm{t}$
$\Delta$ Depr $_{\mathrm{t}}$
: Depreciation and Amortization Expense pada tahun $\mathrm{t}$
At -1
: Total Assets 1 tahun sebelum t

Adanya keterbatasan data, maka dalam penelitian ini menggunakan metode penghitungan NDA yang sederhana, yaitu Industry Adjusted Model. Model ini menggunakan asumsi yang sama dengan market adjusted model dalam menghitung return sekuritas. Berdasarkan market adjusted model, penduga yang terbaik untuk mengestimasi return suatu sekuritas adalah return indeks pasar pada saat tersebut. Model ini tidak memerlukan periode estimasi untuk membentuk model estimasi karena return sekuritas yang diestimasi adalah sama dengan return indeks pasar.

Analog dengan market adjusted model, maka NDA berdasarkan industry adjusted model berasumsi bahwa penduga yang terbaik untuk mengestimasi NDA pada tahun $\mathrm{t}$ adalah total accruals market (dalam hal ini industri, yaitu perusahaan yang melakukan IPO maupun non IPO) pada periode yang bersangkutan. Model ini dapat menggunakan ukuran tendensi sentral dalam aplikasinya, baik mean maupun median.

Industry adjusted model dapat dirumuskan sebagai berikut:

$\mathrm{NDA}_{\mathrm{t}}=$ Mean atau Median $\left(\mathrm{TA}_{\mathrm{tIND}}\right)$

* Corresponding author's e-mail: ekhatyo11@gmail.com 
Jurnal Ilmiah Akuntansi Universitas Pamulang - Vol. 7, No. 2, Juli 2019 - Marito \& Prasetya

Keterangan:

$\mathrm{NDA}_{\mathrm{t}}=$ Non Discretion Accruals pada periode $\mathrm{t}$

$\mathrm{TA}_{\mathrm{tIND}}=$ Total Accruals Industri Perusahaan IPO maupun Non IPO

\section{Metode Pengumpulan Data Sampel}

Penentuan sampel yang dijadikan sebagai data yang akan diteliti dilakukan secara purposive, dengan penentuan kriteria sebagai berikut:

1. Emiten merupakan perusahaan yang melakukan IPO tahun 2000 sampai dengan 2004.

2. Emiten berada pada industri manufaktur dan industri lain selain jasa dan perbankan.

3. Emiten memiliki tahun fiskal 1 Januari sampai dengan 31 Desember dengan ringkasan laporan keuangan dalam prospektus minimal 2 tahun penuh ( 2 annual reports) sebelum melakukan $I P O$. bawah ini:

Agar lebih jelas, maka pemilihan sampel diuraikan pada tabel berikut di

\begin{tabular}{|l|l|l|}
\hline No & Keterangan & Jumlah \\
\hline 1 & $\begin{array}{l}\text { Perusahaan yang listing di BEI sejak tahun 2000 sampai } \\
\text { dengan 2004 }\end{array}$ & $\begin{array}{l}130 \\
(59) \\
(20)\end{array}$ \\
3 & $\begin{array}{l}\text { Perusahaan Jasa dan Perbankan } \\
\text { Perusahaan dengan data yang tidak lengkap }\end{array}$ & 51 \\
\hline
\end{tabular}

\section{Metode Analisis Data}

Prosedur yang peneliti ambil dalam melakukan analisis data dapat diuraikan sebagai berikut:

1. Langkah pertama adalah menghitung discretionary accruals atas semua data sampel yang telah tercatat.

2. Langkah kedua adalah, keseluruhan variabel, (baik dependent maupun independent variable) dimasukkan dalam sel analisis.

3. Langkah ketiga, sebelum dilakukan pengujian terkait kekuatan pengaruh independent variable terhadap dependent variable, maka terlebih dahulu dilakukan pengujian untuk membuktikan bahwa pada tahun yang diamati telah terindikasi adanya tindakan earnings management. Variabel $\mathrm{DA}_{t}$ diuji dengan menggunakan uji t. Jika t-hitung $>$ dari $(+)$ t-tabel atau t-hitung $<(-) \mathrm{t}-$ tabel maka pada tahun tersebut terindikasi adanya tindakan earnings management.

Model yang digunakan adalah sebagai berikut:

Keterangan:

$$
\mathrm{Y}=\beta 0+\beta 1 \mathrm{X} 1+\beta 2 \mathrm{X} 2+\beta 3 \mathrm{X} 3+\mathrm{e}
$$

$\mathrm{Y}=$ Discretionary accruals

b0 $\quad=$ Konstan

$\mathrm{X} 1=$ Reputasi auditor

$\mathrm{X} 2=$ Leverage

* Corresponding author's e-mail: ekhatyo11@gmail.com 
Jurnal Ilmiah Akuntansi Universitas Pamulang - Vol. 7, No. 2, Juli 2019 - Marito \& Prasetya

$\mathrm{X} 4=$ Persentase saham yang ditawarkan kepada publik saat $I P O$

$\beta 1-\beta 3=$ Koefisien regresi

$\mathrm{e} \quad=$ Kesalahan pengganggu

4. Langkah keempat adalah melakukan pengujian hipotesis melalui pengujian regresi yang terdiri atas beberapa tahap yaitu:

1) Uji normalitas

Pengujian ini bertujuan untuk melihat apakah data terdistribusi normal atau tidak. Supaya data berdistribusi normal maka outliers (data yang mempunyai nilai di luar batas normal) dihilangkan. Metode ini disebut dengan trimming. Nilai statistiknya dapat diketahui dengan KolmogorofSmirnov test (liliefors). Jika nilai liliefors-hitung $<$ nilai liliefors-tabel maka data berdistribusi normal (Hair et al., 1998).

2) Goodness of Fit Test

Pengujian ini dimaksudkan untuk mengetahui tingkat ketepatan yang paling baik dalam analisis regresi yang dinyatakan dengan koefisien determinasi majemuk (R2). $\mathrm{R} 2=1$ berarti independent variable berpengaruh sempurna terhadap dependent variable, sebaliknya jika R2 = 0 berarti independent variable tidak berpengaruh terhadap dependent variable.

3) Uji F

Pengujian ini untuk mengetahui apakah independent variable secara serentak berpengaruh terhadap dependent variable. Jika nilai F-hitung > F-tabel maka independent variable secara serentak berpengaruh terhadap dependent variable.

4) Uji t

Pengujian ini untuk mengetahui apakah independent variable secara individu berpengaruh terhadap dependent variable. Jika nilai t-hitung $>$ $(+) \mathrm{t}$ - tabel atau thitung $<(-) \mathrm{t}$-tabel maka independent variable secara individu berpengaruh terhadap dependent variable.

5) Kemudian, melakukan pengujian dengan Teknik Uji Asumsi Klasik Regresi yang terdiri atas:

(1) Uji autokorelasi

Untuk mengetahui apakah terdapat korelasi yang sempurna antara anggotaanggota observasi. Pendeteksiannya dengan menggunakan Durbin Watson Test (Gujarati 1991: 201). Jika nilai Durbin Watson di antara $d u$ ( Durbin Watson maksimal) dan 4-dl (Durbin Watson minimal) maka tidak terjadi autokorelasi.

(2) Uji multikolinearitas

Multikolinearitas merupakan suatu keadaan dimana terdapat hubungan yang sempurna antara beberapa/semua independent variable dalam model regresi. Pendeteksiannya dilakukan dengan menggunakan tolerance value dan VIF (Variance Inflation Factor). Jika nilai tolerance value $>0,10$ dan $V I F<10$ maka tidak terjadi multikolinearitas.

(3) Uji heterokedastisitas

* Corresponding author's e-mail: ekhatyo11@gmail.com 
Jurnal Ilmiah Akuntansi Universitas Pamulang - Vol. 7, No. 2, Juli 2019 - Marito \& Prasetya

Heterokedastisitas berarti terdapat varian yang tidak sama dalam kesalahan pengganggu. Pendeteksiannya dilakukan dengan metode Glejser (Arief 1992: 134) yaitu dengan meregresikan nilai absolut residuals. Jika t-hitung berada diantara $\pm \mathrm{t}$-tabel, maka tidak terjadi heterokedastisitas.

\section{HASIL DAN PEMBAHASAN}

\section{Hasil Analisis Data}

Hasil uji normalitas menunjukkan 17 nilai outliers, sehingga data yang diuji lebih lanjut berjumlah 34 perusahaan, dengan nilai liliefors-hitung $=0.08$ dan liliefors-tabel $=0,23$ Sehingga liliefors-hitung $<$ liliefors-tabel yang berarti data berdistribusi normal.

Hasil pra pengujian (untuk mengetahui apakah pada tahun yang diamati terjadi earnings management) menunjukkan nilai t-hitung $=9.055$ dan $\mathrm{t}$-tabel $= \pm$ 2,021 sehingga $\mathrm{t}$-hitung $>\mathrm{t}$-tabel yang berarti pada tahun $\mathrm{t}$ (Periode terakhir sebelum $I P O$ ) perusahaan sampel terindikasi melakukan earnings management.

Berdasarkan hasil pengolahan data diperoleh persamaan regresi $\mathrm{Y}=-0,169+$ $0,096 \mathrm{X} 1+0,021 \mathrm{X} 2+0,029 \mathrm{X} 3+0,019 \mathrm{X} 4+\mathrm{e}$, dimana $\mathrm{Y}=$ discretionary accruals sebagai proxy atas earnings management, $\mathrm{X} 1=$ reputasi auditor, $\mathrm{X} 2=$ jumlah dewan direksi, $\mathrm{X} 3=$ leverage, $\mathrm{X} 4=$ persentase saham yang ditawarkan kepada publik saat $I P O$, dan $\mathrm{e}=$ kesalahan pengganggu.

Pengujian Goodness of Fit Test menunjukkan nilai R2 = 36,3 yang berarti hanya sebesar $36,3 \%$ dependent variable dapat dijelaskan oleh independent variable. Hasil uji $\mathrm{F}$ menunjukkan nilai $\mathrm{F}$-hitung $=4,130$ dan $\mathrm{F}$-tabel $=2,61$ karena F-hitung > F-tabel maka secara serentak independent variable berpengaruh terhadap dependent variable.

Hasil uji t dan pengujian hipotesis ditunjukkan sebagai berikut:

Tabel 1.

Hasil Uji Hipotesis

\begin{tabular}{|l|l|l|l|}
\hline Variabel & t-hitung & t-tabel & Keterangan \\
\hline X1 & 2,010 & $\pm 2,021$ & H0 diterima, atau Ha ditolak \\
X2 & 3,497 & $\pm 2,021$ & H0 ditolak, atau Ha diterima \\
X3 & 1,258 & $\pm 2,021$ & H0 diterima, atau Ha ditolak \\
\hline
\end{tabular}

(Sumber: Hasil Olah Data Peneliti)

Hasil uji asumsi klasik regresi diuraikan sebagai berikut:

1. Uji autokorelasi

Hasil Durbin Watson Test menunjukkan nilai Durbin Watson-hitung $=1,931$ sedangkan $\mathrm{du}=1,728$ dan $\mathrm{dl}=1,208$, yang keduanya diperoleh dari table nilai Durbin Watson. Jadi 1,728 $<D W$-hitung $<2,729$, dengan demikian tidak terjadi autokorelasi.

2. Uji Multikolinearitas

Tabel 2. 
Jurnal Ilmiah Akuntansi Universitas Pamulang - Vol. 7, No. 2, Juli 2019 - Marito \& Prasetya

Hasil Uji Multikolinearitas

\begin{tabular}{|c|c|c|c|}
\hline Variabel & Tolerance Value & VIF & Keterangan \\
\hline X1 & 0,983 & 1,017 & Tidak kolinear \\
X2 & 0,987 & 1,013 & Tidak kolinear \\
X3 & 0,949 & 1,054 & Tidak kolinear \\
\hline
\end{tabular}

(Sumber: Hasil Olah Data Peneliti)

3. Uji Heterokedastisitas

Tabel 3.

Hasil Uji Heterokedastisitas

\begin{tabular}{|c|c|c|c|}
\hline Variabel & t-hitung & t-tabel & Keterangan \\
\hline X1 & 0,862 & $\pm 2,021$ & Tidak terjadi \\
X2 & $-0,593$ & $\pm 2,021$ & heterokedastisitas \\
X3 & $-0,233$ & $\pm 2,021$ & Tidak terjadi \\
& & & $\begin{array}{c}\text { heterokedastisitas } \\
\text { Tidak terjadi } \\
\end{array}$ \\
& & & heterokedastisitas \\
\hline
\end{tabular}

(Sumber: Hasil Olah Data Peneliti)

\section{Pembahasan}

Mengacu pada hipotesis yang telah dirumuskan, maka berdasarkan pengujian data diperoleh hasil bahwa hanya leverage saja yang berpengaruh terhadap earnings management. Hal ini dapat dijelaskan dengan uraian sebagai berikut:

1. Bahwa perusahaan mengalami default (tidak dapat melunasi kewajibannya pada saat jatuh tempo) karena kesulitan keuangan. Perusahaan semacam ini sangat rentan terhadap tindakan earnings management. Biasanya tindakan earnings management dilakukan oleh perusahaan ketika ia mengetahui terancam default, yaitu dengan memilih metode akuntansi yang dapat meningkatkan labanya. Tindakan tersebut dapat memberikan posisi bargaining yang lebih baik saat terjadi negosiasi ulang apabila perusahaan benar-benar tidak dapat melunasi kewajibannya.

2. Leverage yang terlalu tinggi dibandingkan leverage industri pada umumnya, mengakibatkan suatu perusahaan kesulitan untuk memperoleh dana tambahan dengan melakukan pinjaman. Hal ini disebabkan karena kreditur menolak meminjamkan uang lebih banyak sebab kreditur memerlukan jaminan atas dana yang dipinjamkan, maka akan sulit bagi perusahaan yang mempunyai leverage tinggi meminjam dana tambahan tanpa menambah ekuitas terlebih dahulu. Oleh karena itu perusahaan melakukan go public atau IPO dengan tujuan menambah ekuitas melalui penerbitan saham baru, disamping itu dengan go public perusahaan dapat memperluas pencarian dana.

Walaupun biaya untuk go public relatif cukup besar dan harus menanggung resiko berkurangnya kendali atas perusahaan, tetapi dengan go public perusahaan mendapat sedikitnya 2 keuntungan, yaitu memperoleh suntikan dana segar yang cukup besar dari emisi saham baru dan kemungkinan besar

* Corresponding author's e-mail: ekhatyo11@gmail.com 
Jurnal Ilmiah Akuntansi Universitas Pamulang - Vol. 7, No. 2, Juli 2019 - Marito \& Prasetya

kreditur akan menambah dana yang dipinjamkannya karena resiko kerugian akan ditanggung bersama investor.

Pada kasus ini earnings management dilakukan terhadap laporan keuangan yang termuat dalam prospektus dengan tujuan mempengaruhi persepsi investor atas kinerja perusahaan, sehingga investor mau menanamkan modalnya.

\section{KESIMPULAN}

Penelitian ini bertujuan untuk menguji dan memperoleh bukti empiris pengaruh reputasi auditor, leverage, dan persentase saham yang ditawarkan kepada publik saat IPO terhadap earnings management, yang di-proxy-kan dengan discretionary accruals.

Berdasarkan hasil pengujian hanya leverage saja yang berpengaruh signifikan terhadap earnings management. Hasil penelitian ini mendukung temuan Dechow et.al (1996) bahwa debt motivation yang salah satu proxy-nya adalah leverage, berpengaruh signifikan terhadap earnings management.

Perusahaan yang terancam default cenderung melakukan earnings management dengan menaikkan laba. Hal ini dilakukan dalam rangka memperbaiki posisi bargainingnya saat negosiasi ulang atau perusahaan melakukan go public untuk mendapatkan dana segar karena kesulitan mencari dana pinjaman. Earnings management untuk perusahaan yang go public dilakukan pada prospektus laporan keuangan perusahaan sebelum IPO agar investor tertarik menanamkan modalnya.

Penelitian ini memiliki beberapa keterbatasan, antara lain: periode pengamatan yang relatif pendek, model penghitungan discretionary accruals dan total accruals yang masih sederhana, dan faktor-faktor yang diteliti sebagian besar bersifat kuantitatif. Namun demikian penelitian ini diharapkan dapat menjadi referensi bagi peneliti-peneliti lain yang tertarik untuk meneliti fenomena earnings management dan faktor-faktor yang mempengaruhinya.

Implikasi bagi penelitian yang akan datang ialah hendaknya penelitian yang akan datang dapat meningkatkan cara mendeteksi tindakan earnings management dengan model yang telah teruji power of test-nya. Selain itu penelitian yang akan datang juga dapat mengamati earnings management dengan periode waktu, jumlah sampel, maupun event yang berbeda. Event merger dan akuisisi, adopsi standar akuntansi dan peraturan perpajakan yang lebih dini, maupun krisis ekonomi dapat dijadikan event pengamatan atas tindakan earnings management.

\section{DAFTAR PUSTAKA}

Anthony, Robert N. and Vijay Govindarajan (1995), Management Control Systems, Irwin: Homewood, Illinois.

* Corresponding author's e-mail: ekhatyo11@gmail.com 
Jurnal Ilmiah Akuntansi Universitas Pamulang - Vol. 7, No. 2, Juli 2019 - Marito \& Prasetya

Belkaoui, Ahmed R (1993), Accounting Theory , Cambridge:The University Press.

Dechow, P.M., R.G. Sloan, and A.P. Sweeney (Spring 1996), "Causes and Consequences of Earnings Manipulation: Analysis of Firms Subject to Enforcement Actions by The SEC", Contemporary Accounting Research, page 1-36.

Financial Accounting Standard Boards. 1987, Statement of Financial Accounting Concepts, No. 1,2,5,6, Mc. Graw Hill.

Ikatan Akuntan Indonesia. (1994), Standar Akuntansi Keuangan.

Jensen, MC. (1993), "The Modern Industrial Revolution, Exit, and The Failure of Internal Control Systems", The Journal of Finance..

Jiambalvo, James. (1996), "Discussion of Causes and Consequences of Earnings Manipulation: An Analysis of Firm Subject to Enforcement Actions by The SEC", Contemporary Accounting Research, page 37-47.

Scott, William, R. (1997), Financial Accounting Theory, International Edition, New Jersey: Prentice-Hall, Inc.

Singarimbun, Masri, dan Sofyan Effendi. (1982), Metode Penelitian Survei, Jakarta: LP3ES.

Sugiri, Slamet. (1998), "Earnings Management: Teori, Model, dan Bukti Empiris", Telaah, hal 1-18.

Sunariyah (1993), Informasi Prospektus dan Ketepatan Peramalan Laba, Tesis S2 Universitas Gajah Mada, Yogyakarta.

Watts, Ross L., and J L Zimmerman. (1986), Positive Accounting Theory, New Jersey: Prentice-Hall, Inc.

* Corresponding author's e-mail: ekhatyo11@gmail.com 